\title{
RISKING CIVILIAN LIVES TO AVOID HARM TO CULTURAL HERITAGE?
}

\author{
William Bülow
}

7 He Destruction of tangible cultural heritage, when it is either deliberately attacked or accidentally destroyed, has long been a part of war and L armed conflict. ${ }^{1}$ While it has not received much attention from philosophers working on just war theory, the destruction of tangible cultural heritage in war gives rise to a range of normative questions. For example, what, if anything, ought to be done in order to protect cultural heritage during conflict? ${ }^{2}$

The aim of this paper is not to provide an exhaustive answer to this question. Instead, I focus merely on one question in this context-namely, under which conditions are combatants morally permitted to impose non-negligible risks of serious harm —including lethal harm — on innocent civilians (henceforth civilians) in order not to endanger tangible manifestations of cultural heritage? To illustrate, imagine that a commander can choose between two strategies, $A$ and $B$. A means that the troops will move close to a geographically isolated heritage site, whereas $B$ means that the troops will move close to an area populated by civilians. The commander is aware that both $A$ and $B$ are risky and will inevitably impose a substantial risk of harm either to the civilians or to the heritage site, should the troops come under enemy fire. Assuming that $A$ and $B$ have roughly the same chance of success, what would be the moral justification for choosing $B$ rather than $A$ ?

Building on a previous account of the value of cultural heritage proposed by Janna Thompson, I argue that cultural heritage is valuable because it contributes to making human lives meaningful and valuable. ${ }^{3}$ Taking this account as

1 Van der Auwera, "UNESCO and the Protection of Cultural Property during Armed Conflict"; Bevan, The Destruction of Memory; Stone, "The Challenge of Protecting Heritage in Times of Armed Conflict."

2 For discussion of this and related questions, see Thompson, "War and the Protection of Property”; Matthes, “'Saving Lives or Saving Stones?'”; and Frowe and Matravers, "Conflict and Cultural Heritage." For a recent historical discussion of the place of cultural heritage protection within the just war tradition, see also Brunstetter, "A Tale of Two Cities."

Thompson, "War and the Protection of Property." 
my point of departure, I critically examine the claim that commanders should be prepared to risk the lives of civilians in order not to endanger tangible cultural heritage. ${ }^{4}$ I propose that imposing non-consensual risks of serious harm on civilians constitutes a moral wrong that can be justified only in order to avoid a greater evil. I argue that damage to cultural heritage sites rarely constitutes the greater evil when weighed against the imposition of non-consensual risks of serious harm to civilians, especially when the risk is substantial. Still, imposing substantial risks of serious harm might be morally permissible under the condition that they are consensual. I grant that it is natural to suppose that at least some individuals might be prepared to bear at least some risks in order to avoid harm to tangible cultural heritage. Yet, as I argue here, it is not clear that this is something that commanders should take into account in their deliberations about what to do. Due to the nature of armed conflict and due to epistemological constraints, it is hard to distinguish those individuals who consent from those who do not. Moreover, even if a subset of those whose interests are at stake have consented to the risk, it does not follow that it is morally permissible to impose a risk of serious harm on the group as a whole.

The paper is structured as follows. In section 1, I outline and defend what I consider to be the most promising account of the value of cultural heritage and why heritage merits at least some protection in war. This section serves as the general background for the discussion that follows. In section 2, I focus on a proposal offered by Thompson, according to which commanders should be prepared to sometimes risk the lives of civilians in order not to endanger heritage sites that have outstanding universal value. I argue that Thompson's account is incomplete as it fails to address the important questions of how to decide which heritage sites merit protection and why it is morally permissible to risk civilians' lives, given how they have neither waived nor forfeited their usual right against harm. In section 3, I explore the circumstances under which it might be morally

4 Similar to recent philosophical work on the protection of heritage in war (see note 2), this paper focuses on tangible manifestations of cultural heritage, including such things as historical buildings and heritage sites. One should note, however, that cultural heritage encompasses more than that and includes practices, customs, and other intangible manifestations of a culture. Also, one should note that some of the reasons why tangible cultural heritage is deemed valuable extend to intangible heritage too. That said, I believe that the protection of tangible heritage merits special attention, most notably because it often gives rise to important but difficult moral conflicts in war. For example, while there certainly will be exceptions, protecting intangible heritage will often coincide with the direct protection of individuals' lives or liberties. In contrast, it is reasonable to assume that the protection of a cultural heritage site during conflict will sometimes stand in direct conflict with the protection of civilian lives, for instance when it comes to the distribution of risks or resources allocated for their protection. 
permissible to impose risks on civilians in order to avoid harm to cultural heritage in greater detail. Section 4 concludes.

\section{THE VALUE OF CULTURAL HERITAGE}

Those who believe that cultural heritage merits special protection in war typically stress that cultural heritage has intrinsic, rather than merely instrumental, value. ${ }^{5}$ That is, we value this type of thing for its own sake and not solely because it serves some other valuable end. While I am sympathetic to this view, I am skeptical of whether it is helpful for assessing whether it can be morally permissible for combatants to impose risks on civilians in order to avoid harm to tangible cultural heritage in war. After all, civilians are intrinsically valuable too. To make progress on this issue, we need an account of how valuable cultural heritage is relative to other things.

I suggest that a more fruitful starting point is to consider how cultural heritage might contribute to human flourishing. Perhaps the most careful analysis of cultural heritage in these terms comes from Janna Thompson. ${ }^{6}$ According to Thompson, the requirements of just war theory are motivated by the overall importance of limiting the negative impact of war, such that important values can survive armed conflict. Among these requirements is the principle of civilian immunity, which grants civilians immunity from intentional as well as unnecessary and disproportionate harm. ${ }^{7}$ According to Thompson, the principle of civilian immunity entails a duty to protect not only the lives of civilians, but also the conditions that help make their lives worth living. Thompson's argument builds on a number of claims, but its basic assumption is that respect for the value of human life requires more than protecting what Thompson refers to as "mere life."

Life is valuable, but for most people it isn't the only thing of supreme value. Indeed, life without other valued things is for many people barely tolerable-or perhaps not tolerable at all. Because mere life can be a life without meaning or even a life not worth living, many philosophers have argued that it is not life itself that is valuable but life that has value to the person who lives it. One of the implications of this plausible view is that it is not enough merely to protect life. We must also endeavour to preserve and protect those conditions that enable people to value their lives. ${ }^{8}$

5 See, e.g., Harding, "Value, Obligation and Cultural Heritage."

6 Thompson, "War and the Protection of Property."

7 Walzer, Just and Unjust Wars.

8 Thompson, "War and the Protection of Property," 245. 
This is a plausible view: caring for people's lives requires caring for and respecting the conditions that help make their lives go well and provide them with meaning. What these conditions are, exactly, is of course to a large extent an individual matter. Yet, as Thompson points out, property often is conducive to the type of condition under which people are able to lead meaningful and valuable lives. This includes private property as well as public or collective property. She writes:

A community is bound together through the places where people live and work, and its public buildings provide the infrastructure for their social relationships. Schools and places of worship or public assembly are the focus of the lives of many individuals, and provide resources that help to make their lives worth living. ${ }^{9}$

This also holds for tangible cultural heritage. Thompson suggests that because of "their central place in the lives of individuals and the practices of their communities, respect for civilians requires that places of worship, heritage buildings, and monuments should get at least as much protection from attack as civilian homes, and that looting of these things should be strictly prohibited." ${ }^{10}$

Before I discuss Thompson's account in greater detail, I should make one important remark. While it is commonly asserted that cultural heritage has positive value, one should bear in mind that there are examples of tangible cultural heritage that do not. As Erich Matthes points out, the appeal to heritage is sometimes used to excuse or justify certain actions that we would otherwise consider morally wrong. ${ }^{11}$ To take one example, the claim that confederate monuments found in the us should not be removed is sometimes motivated by an appeal to heritage, even though these monuments unjustly harm African Americans. ${ }^{12}$ Throughout the rest of this paper, I assume that the type of cultural heritage monuments or sites that prima facie merit protection in war are those that do not cause unjustified harm. ${ }^{13}$

9 Thompson, "War and the Protection of Property," 246.

10 Thompson, "War and the Protection of Property," 252.

11 Matthes, "Who Owns Up to the Past?"

12 For a discussion of the obligation to remove confederate monuments on the basis that they cause harm to undeserving individuals, see Timmerman, "A Case for Removing Confederate Monuments."

13 The fact that the harm is unjustified is important here. While it needs to be fleshed out in greater detail (which is beyond the scope of this paper) I think it is fair to say that the harm caused by the confederate monuments is unjust because of how it is connected to the fact that these monuments express and commemorate historical injustices. In contrast, the fact that idols would cause distress to members of Isis may, at best, qualify as a type of harm, but not an unjustified one. 
As an argument for the protection of cultural heritage during armed conflict, Thompson's account can be formulated as follows:

P1. Combatants should respect civilian immunity.

P2. Civilian immunity requires not only the protection of "mere life," but also respecting and protecting those conditions that contribute to making human lives meaningful and valuable.

P3. Tangible cultural heritage is among the conditions that contribute to making human lives meaningful and valuable.

c. Combatants should respect tangible cultural heritage and take measures to avoid its destruction.

This argument should not be conflated with the fairly common type of argument that cultural heritage ought to be protected in war because doing so would be instrumental in achieving some other end, for which the use of military force could be morally justified. For example, according to one argument found in the debate on cultural heritage protection in war, the deliberate destruction of cultural heritage should be prevented because doing so will ultimately save human lives. ${ }^{14}$ Another argument is that preventing the looting of museums or heritage sites denies illicit funding to terrorist organizations. ${ }^{15}$ These arguments concern whether combatants ought to sometimes prevent others from deliberately destroying cultural heritage, either because this is in itself a just cause or because it might help promote one. In contrast, the argument I formulated above suggests that combatants, when pursuing a just cause, should take precautionary measures in order not to endanger tangible cultural heritage as a side effect. This is so even when such precautions do not serve any other valuable end, such as saving human lives or preventing further harms.

Given the complexity of human flourishing, Thompson's account is compatible with a range of explanations for why harm to cultural heritage in war ought to be avoided. For example, in addition to their importance for local communities,

14 This sort of argument is often made with reference to a famous quote by Raphael Lemkin: "Burning books is not the same as burning bodies, but when one intervenes ... against mass destruction of churches and books one arrives just in time to prevent the burning of bodies" (cited in Bevan, The Destruction of Memory, 15). The underlying thought in this type of argument, then, is that the deliberate destruction of cultural heritage might lead to the deliberate killing of innocent individuals. For critical assessment of this sort of argument, see Frowe and Matravers, "Conflict and Cultural Heritage"; and Matthes, "'Saving Lives or Saving Stones?"”

15 Frowe and Matravers, "Conflict and Cultural Heritage”; Matthes, “'Saving Lives or Saving Stones?'”; Stone, "A Four-Tier Approach to the Protection of Cultural Property in the Event of Armed Conflict." 
Thompson argues that tangible cultural heritage sometimes merits special protection because of its great aesthetic, scientific, or educational value. ${ }^{16}$ In such a case, the object of cultural heritage might not only have value to the specific cultural group that directly engages with it, but is also potentially valuable to all humankind. "Paintings or artefacts of great aesthetic value," Thompson argues, "should be preserved and protected so that they can continue to be appreciated by present and future generations." ${ }^{\prime 17}$ Elsewhere, Thompson suggests that being exposed to great art, and learning to appreciate it, can be life enhancing, and allows for a type of experience that "contributes profoundly to an individual's experience and self-development."18 This type of experience, she argues, is "particularly profound if individuals are able to experience the works themselves, as opposed to reproductions or photographs." ${ }^{19}$ This also holds for objects or sites of great historical or educational value, as they too provide opportunities for life-enriching experiences. In the case of historical buildings and monuments, we should add that at least some aesthetic properties are not only better appreciated if individuals are able to directly engage with this type of object, but can only be appreciated and experienced through direct interaction with it. As Carolyn Korsmeyer argues, the "genuineness" or "authenticity" of some cultural heritage monuments is in itself an aesthetic property and allows for a particular aesthetic experience associated with the encounter with the "real" thing. Such objects, Korsmeyer argues, provide an impression of a "transitivity of touch" and are valuable in part because they have the capability "to bring the past into the present, providing an aesthetical encounter of a particular charm or thrill." This type of property might of course be lost if the historical object is either severely damaged or destroyed altogether. ${ }^{21}$

Another important role of cultural heritage is that it provides individuals with the basis of a shared identity and sense of belonging. That tangible cultural heritage can be conducive to this end is illustrated by this quote from a local

Thompson, "War and the Protection of Property."

Thompson, "War and the Protection of Property," 252; see also Harding, "Value, Obligation and Cultural Heritage."

Thompson, "Art, Property Rights, and the Interests of Humanity" 550.

Thompson, “Art, Property Rights, and the Interests of Humanity," 550.

Korsmeyer, Things, 162.

For a view somewhat similar to Korsmeyer's, see Janowski, “Bringing Back Bamiyan's Buddhas." This sort of view is not undisputed (see, e.g., Matthes, "Authenticity and the Aesthetic Experience of History") or without problems. For example, one could ask what it means for a cultural object to retain the same identity over time. For discussion on this issue, see Korsmeyer, Things, ch. 5 . 
militia commander, following IsIs destruction of the ancient Assyrian city of Nimrud in northern Iraq:

For us in this village, Nimrud is one of the first things we saw when we were born. This ancient city and its antiques it's a part of our life.... I lost something priceless. My sorrow lies in the fact that we lost something that we were so proud of when tourists came to our country. The pride we felt for them and our civilization, what our forefathers made for our country, it's a subject that's part of our soul. When the Saddam regime fell in 2003, we and our clans protected those monuments because there was no central Iraqi government. We were able to protect the palace from looting. But ISIS, ISIS did something we were not expecting. ${ }^{22}$

The claim that cultural heritage is important for people's sense of belonging and social identity, and hence brings value to their lives, is commonly evoked in the debate on cultural heritage protection in war. For example, Weiss and Connelly argue that the imperative of protecting tangible cultural heritage is not in conflict with that of protecting life. ${ }^{23}$ Culture and people, they claim, are in fact inseparable, and culture is just as essential for life as air and water. This claim is much stronger and more controversial than Thompson's, as it suggests that valuable human life is impossible without a tangible cultural heritage. In contrast, I take it that Thompson is making the more modest—and much more plausibleclaim that tangible cultural heritage is among the sort of things that can enrich people's lives and provides an important resource that often helps make people's lives valuable to them. Yet, in making their argument, Weiss and Connelly seem to share Thompson's basic assumption that in war it is not only "mere life" that ought to be protected, but also the conditions that enable people to value their lives. In line with Thompson's account, Weiss and Connelly suggest that "the destruction of cultural heritage is ruinous for cultural identity and social cohesion. The buildings, museums, libraries, and infrastructure around which societies organize themselves in part help define a people." ${ }^{4}$ Thus, something along the lines of $\mathrm{P}_{3}$ in the above argument appears to be fairly widely accepted.

It should be observed that the various explanations of how a cultural object can provide meaning and value to individual lives do not always overlap. For example, while some monuments are possibly valuable to all of humankind, pri-

22 Cited in Matthes, "'Saving Lives or Saving Stones?" 69.

23 Weiss and Connelly, "Cultural Cleansing and Mass Atrocities Protecting Cultural Heritage in Armed Conflict Zones.”

24 Weiss and Connelly, "Cultural Cleansing and Mass Atrocities Protecting Cultural Heritage in Armed Conflict Zones," 13. 
marily because of their great aesthetic qualities or historical significance, they may have little relevance for local individuals' sense of belonging or shared identity. Similarly, a cultural object that has great value for a local community may have very little aesthetic value to individuals outside this cultural group. ${ }^{25}$

The fact that some cultural objects that have great aesthetic, historical, or educational value provide most individuals (including future generations) with the opportunity for life-enhancing experiences suggests that these objects have universal value. Because of their potential value for most individuals, and how they might contribute to human flourishing, it is a good thing that objects of this kind exist and continue to do so. We all therefore have good moral reason to respect this type of object. Things are a bit different when a particular cultural heritage monument or site is valuable primarily because it provides a basis for community and shared identity. In this case, an important part of the value of a heritage site is often local and depends on its relation to the specific agents in question. ${ }^{26}$ For example, as noted in the case of Nimrud, living in a specific place, with a specific historical narrative and certain connection to the past, might provide meaning to particular individuals' lives. This is because of their relationship to the same physical space and how it helps maintain what they perceive as an important and valuable relationship between themselves and other individuals, including the past and future. In this type of case, then, cultural heritage also has great personal value. Its loss would deprive them not only of something that was valuable to them, but also of something irreplaceable that helps provide meaning to their lives. In this case we have reason to respect this type of object because of its value to these identifiable individuals.

These remarks are important, not least because they have implications for when it is morally permissible to impose risks on civilians in order to avoid harm to cultural heritage. Before discussing this issue in greater detail, however, I will first discuss Thompson's proposal that commanders should sometimes be prepared to risk the lives of civilians in order not to endanger heritage sites that have great value to humankind.

25 Thompson, "War and the Protection of Property." It should be noted that this is not the same as saying that a cultural heritage site has either local or universal value. It is possible that it has both.

One should note, however, that there perhaps are cultural heritage sites that are valuable because of how they provide a sense of community for humanity as a whole. In this sense, the basis for community and shared identity that sites of this sort provide is universally valuable. While I do not want to rule out this possibility, I should say that I do think that cultural heritage sites that have this type of value are rare. I suspect that some might argue that the fact that the Notre-Dame fire attracted global attention indicates that it might be valuable in this way. Another candidate, I think, are the Lascaux cave paintings. 
Even if cultural heritage is important, the question remains whether it is important enough to justify imposing non-negligent risks of lethal harm on civilians. Thompson thinks so.

Cultures as well as individuals are likely to have different opinions about how much should be risked in war to save works of art (and which works of art are worth the risks). But there is reason to agree that commanders should be prepared to risk lives in order to protect works which exemplify the achievements of a civilization.... Above all, it should be possible for the opportunities intrinsic to civilized life to survive and be enjoyed by future generations - and these include being able to appreciate its greatest products. ${ }^{27}$

This is consistent with Thompson's account. As we saw above, she argues that respecting life requires not only the protection of "mere life," but also respecting and protecting those conditions that contribute to making people's lives valuable and meaningful. This includes the protection of tangible cultural heritage. In contrast, if one would refuse to bear any risks for the sake of cultural heritage-and especially those of outstanding universal value-this seems to be a violation of this moral commitment.

According to Thompson, then, military commanders should be prepared to impose non-negligible risks on both the lives of civilians and just combatants in order to avoid endangering at least some cultural heritage sites. She contrasts her view with the position that people's lives are infinitely more precious than buildings, according to which no risk whatsoever can be justified in order to avoid harming a cultural heritage site. According to Thompson, it "was this thinking which led to the destruction of Monte Cassino, which most people now see as not justified by military necessity." ${ }^{28}$ However, none of this suggests that it is easy to determine either when it is morally permissible to impose risks on either combatants or civilians, or how large a risk can be justified. "The difficult cases," Thompson writes, "are those where cultural property can be protected only by endangering the lives of civilians or combatants." 29

While she never says so explicitly, I take it that the type of scenario that

Thompson, "War and the Protection of Property," 253.

Thompson, "War and the Protection of Property," 253. Monte Cassino was destroyed by the Allies during the Second World War. For discussion of this case from the perspective of military ethics, see De Lee, "Moral Ambiguities in the Bombing of Monte Cassino."

Thompson, "War and the Protection of Property," 252. 
Thompson has in mind is one where the probability of the risks eventuating in harm might be considerable, but where it is uncertain whether any of the civilians whose lives are at stake will in fact end up being killed. This is different from a scenario where the only way not to endanger a cultural heritage site is to impose a serious risk on a group of civilians, knowing that at least some of them will die as a result. This is much more difficult to justify morally, as it presupposes that it is morally permissible to incidentally kill civilians in order not to endanger a cultural heritage site. But even if Thompson does not accept the imposition of risk in this latter case, her account still faces some initial problems, especially when applied to the case of civilians.

First, it does not give us much guidance besides the claim that commanders should be prepared to risk civilian lives in order to protect works that exemplify "the achievements of a civilization." ${ }^{30}$ This raises the question of what counts as "an achievement of a civilization." I anticipate that one possible response is that this includes cultural heritage sites that have "outstanding universal value," as decided by the UNESCO World Heritage List. But this is not an unproblematic claim. It not only defers the more basic philosophical question-namely, what would justify something going on this list in the first place-but the list as such is also held to be somewhat problematic. As Matthes points out, the World Heritage List is to a large extent Eurocentric and a result of a Western cultural perspective. For example, "almost half of the UnEsco World Heritage sites are in Europe and North America; fewer than 10 percent are in Africa." ${ }^{31}$

Second, even if we can identify those works that exemplify an achievement of a civilization, Thompson never provides a clear argument showing that the duty to protect such works overrides the moral rights of civilians against being seriously harmed. After all, civilians - given that they are not contributing to an unjust threat-have done nothing to forfeit their usual rights against harm, which arguably includes a right also against non-negligible risks of serious harm. This does not mean that civilians may never be harmed in war. Yet, it suggests that civilians may be harmed only if they have either waived their right against harm or if this is required in order to avert a greater evil. As it stands, Thompson does not show that civilians usually waive their rights in this type of case or that their rights against serious risks of harm can be justifiably overridden in order not to endanger a particular cultural heritage site, even if it has outstanding universal value. This is something that cannot be answered merely by comparing the impersonal value of a few human lives to the value of cultural heritage. Rather, part of the difficulty here is to justify, in each and every case, why safeguarding one 
specific tangible manifestation of a heritage warrants imposing significant risks of harm on a specific set of innocent individuals. ${ }^{32}$

The above suggests that more needs to be said before one can settle the question of the conditions under which it is morally permissible to impose non-negligible risks of serious harm to civilians in order to avoid harm to cultural heritage. In particular, it needs to be settled whether imposing substantial risks of harm on civilians in order to avoid harm to tangible cultural heritage can be justified as being the lesser evil, or whether it is reasonable to assume that civilians waive their rights against harm in order to prevent harm to heritage sites or buildings. In the sections that follow I discuss these questions in greater detail.

\section{IMPOSING RISKS AND THE SUPPOSED JUSTIFICATION FOR SAVING HERITAGE}

Individuals have a prima facie right not to be exposed to non-negligible risks of serious harm. ${ }^{33}$ Imposing such risks on others—including civilians—is of course often inevitable in war. Usually, imposing risks in war is morally permissible insofar as the combatants are pursuing a just cause and if the risk imposed on civilians is deemed both necessary and proportionate to the military objective for which these risks are being imposed. The question remains, however, whether it is morally permissible for just combatants to impose either new or greater risks of serious harm on civilians in order to avoid endangering cultural heritage. It will be helpful here to draw on broader work on the ethics of risk imposition.

It is frequently acknowledged that whether a certain type of risk imposition is morally permissible or not depends on a number of factors. Among other things, we must observe whether the risk is voluntary or involuntary, and how the risks and benefits are distributed. ${ }^{34}$ Consider the following example adapted (with some modifications) from Saba Bazargan-Forward: ${ }^{35}$

Assume that there are two possible courses of action. The first course of action imposes a risk that is likely to result in one hundred individuals being seriously harmed, but that also largely improves the overall welfare of one hundred thousand individuals. The risk is voluntary and increases the expected welfare of all of those on whom it was imposed. The second course of action imposes a risk that also improves the overall welfare of

For a similar view about the justifiability of imposing risks of harm to civilians for the sake of protecting cultural heritage, see Frowe and Matravers, "Conflict and Cultural Heritage." Hansson, The Ethics of Risk.

34 See, e.g., Hansson, The Ethics of Risk; Hermansson and Hansson, "A Three-Party Model Tool for Ethical Risk Analysis”; Bazargan-Forward, "Standards of Risk in War and Civil Life." 
one hundred thousand individuals, but is likely to result only in fifty individuals being seriously harmed. Yet, the explanation for this reduction is that the risk has been shifted from those who are antecedently expected to benefit to a group of individuals who are not.

Plausibly, the first alternative action is morally preferable, even if it is likely to result in more individuals being harmed. And assuming that the risk in the second course of action is involuntary, choosing this course of action would be unjust. As Bazargan-Forward points out, the individuals who are harmed by the second course of action are wronged by being non-consensually harmed merely for the sake of benefitting others. This is not the case for the individuals who are harmed by the first course of action. ${ }^{36}$ In other words, the moral disvalue of the type of risk imposed in the second course of action is far greater than that imposed in the first alternative.

It needs to be clarified in what way individuals exposed to non-consensual risks of this sort are wronged. Is being exposed to such a risk wrong in itself or are individuals only wronged by such risk if they actually end up being harmed? In the former case, it needs to be explained how the imposition of pure risk (i.e., risks that do not result in any actual harm) wrongs the victim of this risk imposition. ${ }^{37}$ Plausibly, we wrong others by imposing non-consensual, non-negligible risks of serious harm on them, even when this does not lead to any actual harm. For example, if $A$ forces $B$ to participate in Russian roulette against $B$ 's will, it is reasonable to say that $A$ wrongs $B$, regardless of whether $B$ is physically harmed or not. This is so even if forcing $B$ to participate is the only way to secure an important benefit for some other individual, $C$. The reason for this, I think, is that we typically owe it to others not only to refrain from harming them, but also not to create non-negligible risks of serious harm to them. That is, we have a prima facie duty not to impose non-negligible risks on others, although the strength of that duty may vary depending on how large the probability of the harm eventuating is.

Of course, none of this implies that it is morally permissible to impose only risks that are both voluntary and beneficial for the risk bearer. It can be morally permissible to impose certain risks merely under the condition that they are consensual. If the risk is consensual, we should discount the moral disvalue that this risk imposition would have had, had the risk been non-consensual. ${ }^{38}$ Similarly, some risks might be discounted on the basis that they are among the type 
of risks that individuals reciprocally impose on one another. ${ }^{39}$ In that case, an individual's claim against having to bear the risk is substantially less compared to risks that are not reciprocal. ${ }^{40}$ Also, in cases where risks must be distributed among different individuals it is arguably morally permissible to impose the risk on those individuals who are the expected beneficiaries of the risky action rather than those who are not. This is so even if the expected beneficiaries do not consent to this risk. ${ }^{41}$ However, the fact that it might sometimes be morally permissible to impose such a risk does not mean that imposing risks is always justified when it is expected to benefit those on whom they are imposed. As Bazargan-Forward points out, even if there is always a prima facie moral reason to increase the expected welfare of others, this reason is commonly outweighed by our reasons not to act in ways that affect people without their consent. ${ }^{42}$ Still, while imposing non-consensual risks that increase the victim's expected welfare is prima facie wrong, it is arguably not as wrong as imposing non-consensual risks that are expected to decrease the victim's expected welfare. In other words, the moral disvalue of the latter is greater than that of the former. That said, we should note that the fact that a person is the expected beneficiary of a risk might sometimes qualify as a reason for assuming that this person also might consent to the risk. I will return to this point below. For now it suffices to say that the type of risk imposition that has the greatest moral disvalue, and that is therefore the most difficult to morally justify, is that where the risk is both non-consensual and non-beneficial. In those cases we should expect the benefit from imposing such risks to be substantial in order to outweigh the moral disvalue of such acts, especially when we are dealing with high risks of serious harm.

\subsection{Saving Cultural Heritage as the Lesser Evil?}

As pointed out above, imposing considerable risks of serious harm on civilians is often inevitable in war. This is also one of the reasons why it often is so difficult to morally justify resorting to war. Unlike many types of risk impositions

The frequently used example of such risks is those that drivers impose on one another. However, many other types of risks in civil life are also such that we all are usually much better off if we are allowed to impose them or roughly comparable risks on one another.

Bazargan-Forward, "Standards of Risk in War and Civil Life"; Song, "Rights against High-Level Risk Impositions.”

The claim that an individual's beneficiary status can make a moral difference for the distribution of risks of harm in war has been defended by McMahan, "The Just Distribution of Harm between Combatants and Noncombatants"; and Øverland, "High-Fliers." Their arguments are not undisputed, however; see, e.g. Christie, "Distributing Death in Humanitarian Interventions." 
allowed in civil life, civilians are rarely expected to benefit from the risk of being collaterally killed in war. Nor are they voluntarily accepting this risk, or reciprocally imposing similar or comparable risks on others. ${ }^{43}$ Therefore, imposing this type of risk can be justified only if it is the lesser evil. ${ }^{44} \mathrm{I}$ take it that one might be morally justified in imposing a non-consensual, non-beneficial risk of being collaterally killed on civilians if this is both unavoidable in order to protect either oneself (or others) against an unjust aggressor and if the expected harm is proportionate to the type of threat that the unjust aggressor poses. ${ }^{45}$

It is far from clear, however, that a decision to impose either a new or larger non-consensual risk of being collaterally killed on civilians can be morally justified in order not to endanger a cultural heritage site. For example, imagine a military commander who wishes to achieve a military objective, $O$. For simplicity, let us assume that the commander can choose between two strategies: $A$ and $B$. A means that the troops will move close to a geographically isolated heritage site, whereas $B$ means that the troops will move close to an area populated by civilians. The commander is aware that both $A$ and $B$ are risky and will inevitably impose a substantial risk either to the civilians or to the heritage site, should the troops come under enemy fire. Assuming that $A$ and $B$ have roughly the same chance of success, what would be the moral justification for choosing $B$ rather than $A$ ?

Given that the civilians have neither forfeited nor waived their usual right against being exposed to non-negligible risks of serious harm, choosing $B$ over $A$ is morally permissible only if this is the lesser evil. There are good reasons to

43 Bazargan-Forward, "Standards of Risk in War and Civil Life." One possible exception is wars of humanitarian intervention in which the people of an oppressive domestic regime might consent to the intervention of others on their behalf. In such cases, civilians are also the ones who might benefit from this risk. For discussion on this issue, see Bazargan-Forward, "Standards of Risk in War and Civil Life."

44 Following McMahan, I assert there are primarily two types of justifications for the infliction of non-consensual harm in war: liability justifications and lesser-evil justifications (Killing in War; "Proportionality and Necessity in Jus in Bello"). The latter is the one that is relevant in the case of innocent civilians, as they by definition have done nothing to become liable to harm. For a discussion on lesser-evil justifications and their place within deontological moral theories, see Frowe, "Lesser-Evil Justifications for Harming."

A note on proportionality: it is common within the literature on defensive harming to distinguish between narrow and wide proportionality. See McMahan, Killing in War; "Proportionality and Necessity in Jus in Bello." Narrow proportionality is the constraint on the amount of harm that can be imposed on a person that is liable to defensive harm, whereas wide proportionality is the constraint on the amount of harm that can be imposed on an innocent bystander (e.g., a civilian). Both constraints are governed by the importance of the value or rights that are being defended. 
doubt that $B$ is the lesser evil, however. Without denying the importance of cultural heritage, the risk of losing a source for having enriching experiences, or losing something that helps lend a sense of meaning or social cohesion in one's life, is usually not on par with the possible or anticipated loss of life or having to suffer serious bodily injury. In other words, none of the individuals at risk of being harmed by the destruction of this heritage site, should the commander choose $A$, has as strong a claim against having to bear this risk as an individual who is forced to bear the risk of being seriously harmed, should the commander choose $B$. Therefore, if $A$ is indeed morally worse than $B$, this is because the aggregated interests of those who might be harmed, should the heritage site be destroyed, outweigh the aggregated interests of those who have to bear a substantial risk of either being killed or enduring serious bodily harm. It remains unclear whether this really is the case. It is also unclear whether the claims of those individuals at risk of being harmed by the destruction of this heritage site are the type of interest that should be given any weight at all when compared to the much stronger competing claim of not having to bear a high risk of lethal harm. If not, then they should not have any weight even when aggregated.

One helpful, and to my mind plausible, way of thinking about the aggregation of competing claims is developed at length by Alex Voorhoeve, who holds the fairly common view that, when comparing competing claims, only those that are "sufficiently strong relative to the strongest competing claim" are relevant. ${ }^{46}$ In contrast, minor harms are not relevant when compared to claims that are much stronger, and should be discounted. In determining whether a certain claim is relevant or not, Voorhoeve proposes the following test:

$A$ 's claim is relevant to $B$ 's competing claim just in case, in a situation in which $A$ must choose whether to satisfy his claim or B's claim and in which no morally relevant factors apart from the minimally required concern for $B$ stand in the way of $A$ 's acting on his self-interest, he would be permitted to satisfy his own claim. ${ }^{47}$

To put this in the terms of duties: when comparing competing claims, held by different individuals, we should not count the costs that those affected already have a duty to bear, could they alone save a person from suffering the much larger cost that is at stake. To illustrate: most agree that one is not morally required to sacrifice one's legs in order to save someone else's life. On Voorhoeve's view, this implies that we should indeed aggregate the claims that several individuals have in keeping their legs, such that it might outweigh some other individual's

46 Voorhoeve, "How Should We Aggregate Competing Claims?” 66.

47 Voorhoeve, "How Should We Aggregate Competing Claims?" 72. 
competing claim to be saved from certain death. In contrast, one is arguably morally required to bear the cost of never being able to see or visit a specific heritage site or heritage building, should this be the only way to save an innocent person's life. But if this is correct, this means that that individual's interest in being able to appreciate or visit a particular heritage site is not the type of interest that should be aggregated when weighed against an innocent individual's claim against being killed.

This type of reasoning can be extended to include the imposition of risk as well: one is arguably morally required to bear the cost of never being able to visit a specific heritage site or a particular heritage building, should this be the only way to eliminate a high risk of lethal harm befalling an innocent person. This does not mean that there are no risks that can be imposed on civilians in order to avoid endangering a cultural heritage site. After all, the strength of the claim against bearing lethal risks depends on the probability of death. Hence, we should ask at some point whether the probability of lethal harm is sufficiently small that the claim against having to bear that risk no longer trumps the otherwise weaker claim of a larger number of individuals or disallows aggregating the claims of the many. That being said, I do think that this line of reasoning shows that, all else being equal, it is morally impermissible to impose high or relatively high non-consensual risks of serious harm on civilians in order not to endanger tangible cultural heritage.

I suspect that some will resist this view and maintain that there are at least some instances of tangible cultural heritage where the decision to impose even greater risks of serious harm on a limited number of civilians, without their consent, is in fact the lesser evil. In particular, I anticipate that some might argue that this is true in the case of cultural heritage sites of great universal value. By endangering this type of heritage site, one risks harming not only present but also future generations by depriving them of an important resource for having enriching experiences. Given the immensely large number of individuals who might be harmed by this, one might be inclined to say that the loss of at least some instances of cultural heritage might constitute the greater evil. This might be what Thompson has in mind when she argues that commanders should sometimes be prepared to risk the lives of civilians in order for future generations to be able to appreciate outstanding works of art, such as those that represent "the achievements of a civilization."48

Again, this type of argument presupposes that we should indeed aggregate the claims of a larger group of individuals in being able to enjoy a great work of art, and then weigh these aggregated claims against the aggregated claims of

Thompson, "War and the Protection of Property," 253 
some other individuals in not having to bear a non-negligible risk of being killed. However, let us assume for the sake of argument that this is the case. Even so, I think that we should be careful not to make overly drastic estimations of how bad the loss of or damage to a particular cultural heritage site might be. For example, while it is true that the destruction of or serious damage to a cultural heritage site will deprive individuals of an important source for having meaningful and life-enhancing experiences, this does not mean that the chance for having such experiences at all is lost. Nor is it, as Frowe and Matravers point out, clear that damage to a limited set of tangible manifestations of one's cultural heritage inevitably erodes an individual's sense of identity or community. To the contrary, a sense of identity and belonging might still persist even among individuals in communities that suffer widespread losses of their heritage sites, through natural disasters, for example. ${ }^{49}$ We should also bear in mind that monuments or heritage sites of great cultural and aesthetic value that have been severely damaged in war can - at least sometimes-be either restored or reconstructed, as illustrated by several real-life examples. To mention just a few: the reconstructions of the Old Bridge of Mostar and Warsaw Old Town, as well as the restoration of the Frauenkirche in Dresden, show that successful reconstruction is sometimes possible. ${ }^{50}$ Plausibly, individuals might engage with these reconstructed or restored heritage sites in a meaningful and life-enriching manner, even if they are in important ways different from the originals. For example, as Korsmeyer notes in her discussion of the reconstruction of the Old Bridge of Mostar, there is still an important continuity between the "old bridge" and the "new bridge" even if they do not share numerically identical material. ${ }^{51}$ The new bridge looks identical to the old one and occupies the same site and allows "those who cross the bridge to trace the same path as earlier travelers." ${ }^{\text {"In }}$ In that sense, the new bridge too provides individuals with an opportunity to share an experience with others before them, as its shape, function, and location remain the same. As for the question of social identity, we should recognize, as Matthes does, that the process of reconstructing or restoring destroyed cultural heritage can, under the

Frowe and Matravers, "Conflict and Cultural Heritage."

50

Both the historic center of Warsaw and the Mostar Bridge are included on the UNESCO World Heritage List, even if they are reconstructions. For discussion of the Old Bridge of Mostar and the Warsaw Old Town, as well as the many philosophical issues surrounding the restoration of cultural monuments and sites, see Korsmeyer, Things. For a discussion on Frauenkirche, see Janowski, "Resuscitating Bamiyan's Buddhas?"

51 Korsmeyer, Things.

52 Korsmeyer, Things, 151. 
right conditions, prompt us to rethink our relationship to the past, pave the way for greater understanding of heritage, and deepen our relationship to the past. ${ }^{53}$

None of this means that destruction of cultural heritage in war is morally unproblematic. For reasons discussed in section 1, deliberate or accidental destruction of cultural heritage without any just cause is clearly morally wrong. The point I am making here, however, is that imposing substantial risks of harm to tangible manifestations of cultural heritage is a lesser wrong when compared to another wrong: imposing high, or relatively high, non-consensual risks of serious harm to civilians. Therefore, all else equal, combatants pursuing a just cause should abstain from imposing this type of risk to civilians rather than avoiding harm to cultural heritage sites. Note also that I am not suggesting that reconstructions can fully replace what was lost. Again, as discussed in section 1, part of the value often ascribed to heritage monuments is due to their material authenticity. Thus, one remaining question is whether a sufficiently large number of individuals' interests in holding onto tangible heritage monuments with the same material authenticity (in the sense of numerically identical material) can outweigh the interests of a few in not having to bear high risks of serious harm. Even though I do not want to dismiss this interest as being morally irrelevant, I doubt that this is a sufficiently important interest to outweigh the interest in not being exposed to substantial risks of serious harm. Nevertheless, it is sometimes argued that, in those cases where a substantial part of the numerically identical material is being used in the restoration process, the restored heritage monument can retain part of the value that was ascribed to it before it was either severely damaged or destroyed. ${ }^{54}$ If this is so, then there are even more reasons to think that it is an exaggerated claim that the loss associated with the damage or destruction to a cultural heritage monument is the greater evil.

\subsection{A Consent-Based Justification for Saving Cultural Heritage?}

So far, I have focused on the permissibility of imposing non-consensual risks of serious harm on civilians in order not to endanger cultural heritage sites. I have argued that imposing such risks can be justified if they are the lesser evil. Yet, I have suggested that imposing non-consensual risks of serious harm to people rarely constitutes the lesser evil when weighed against the risk of harm to tangible cultural heritage, especially not when the risks of serious harm to people are substantial. This does not mean that imposing non-negligible risks of serious harm on civilians for the sake of protecting cultural heritage is never morally permissible. Rather, it might become morally permissible to impose risks on

Matthes, "Palmyra’s Ruins Can Rebuild Our Relationship with History."

See, e.g., Janowski, “Bringing Back Bamiyan's Buddhas.” 
civilians in order to protect cultural heritage, provided that these individuals consent to this risk.

I think it is reasonable to assert that there are individuals who value certain cultural heritage buildings or sites to such an extent that they might find the imposition of a larger risk of harm on themselves acceptable, especially if the site at risk brings value and meaning to their lives. ${ }^{55}$ Whether a specific individual or group of civilians do consent to the decisions made by combatants in war is of course something that combatants are rarely (if ever) in the position to assess. Therefore, if there is any type of consent that is relevant for the question of imposing risks on civilians for the sake of protecting cultural heritage, it is that of presumed consent. If so, we need to ask what factor, if any, would be a plausible proxy for civilians' consent to this type of risk imposition.

One possibility is to treat the fact that an individual is living and working close to a particular heritage site as a proxy for their consent to bear at least some risk if this is required in order to avoid harm to the same site. ${ }^{56}$ Given that many heritage sites are located in populous places (such as city centers), one can expect that those living close to such heritage sites during an ongoing conflict are the individuals most likely to suffer a substantial risk of harm, should combatants seek to avert harm to the site in question. At the same time, we might suspect that a valued heritage site has particular value to those living close to it. For example, insofar as a certain heritage site is valued in part because of how it provides individuals with a sense of belonging and shared social identity, then we can assume that among those likely to benefit from its continuous existence are the local community and its members. More so, one might think that those individuals who choose to remain in these areas during a conflict do so at least in part because of how it provides them with a range of different resources (social and economic, but also aesthetic and cultural) that help make their lives meaningful. Because of all of this, one might suppose that those who choose to remain close to a heritage site during an ongoing conflict are also likely to consent to at least certain costs to themselves in order to protect this cultural property.

Now there are difficulties with this argument. For example, even if many individuals living close to a heritage site value it for the reasons just discussed, it is far from clear that all individuals living in the area do so equally. To the contrary,

That individuals are prepared to take some risks for the sake of heritage is revealed by the quote from the militia commander cited in section 1 regarding the ancient city of Nimrud. Some might even be prepared to die in order to protect cultural heritage, as is revealed by the acts of Khaled al-Asaad, who was beheaded by IsIs for refusing to tell the terrorist organization where important treasures in Palmyra were hidden. 
even if a certain cultural heritage site has great value to members of the local community still remaining in the area, and is something at least some of these individuals might be willing to accept even a significant risk of lethal harm in order to protect, this is not something that we can simply presume. Rather, it seems to be just as reasonable to assume that some individuals in this group would not consent to such a risk, even if they care deeply about a particular cultural heritage site. It is also reasonable to assume that there might be individuals for whom this particular manifestation of cultural heritage has either no or little value. While it is true that these individuals still have a duty to respect cultural heritage-because of its actual or potential value to others-it is far from obvious that they have a duty to bear risks to their own lives for its sake, especially not high risks. We should also note that many of those who remain in areas where there are cultural heritage sites might not be doing so freely. Rather, they might remain there simply because they have no choice.

In practice, it will be difficult to distinguish those individuals who would consent to the imposition of increased risk from those who would not. Moreover, the fact that some of those whose lives are at risk would consent to the risk of being killed does not make it morally permissible to impose this risk on the group as a whole. To the contrary, if one suspects that at least some of the civilians do not perceive this particular cultural property to be of the kind of value for which they are willing to risk their lives, then it seems like combatants are at risk of imposing a non-consensual risk of serious harm on them for the sake of securing a benefit to others. Given that imposing non-consensual risks of serious harm is typically seen as a moral wrong, and given how the loss of cultural heritage monuments rarely constitutes the greater evil when weighed against the moral disvalue of such acts, imposing this risk on this group of civilians is arguably going to be morally impermissible, especially if the risk in question is substantial.

\section{CONCLUSION}

I have discussed the circumstances under which it is morally permissible to impose non-negligible risks of serious harm (including lethal harm) to civilians in order to avoid endangering tangible cultural heritage during armed conflicts. I have argued that imposing non-consensual risks of serious harm to civilians is justified only if it is the lesser evil. I then raised important concerns about whether such risks ought to be imposed in order to avoid harm to tangible cultural heritage and argued that the loss of heritage buildings rarely qualifies as the greater evil when weighed against civilians' claims against having to bear high 
risks of serious harm. I then suggested that it might be morally permissible to impose non-negligible risks of serious harm on civilians if they consent to the risk. I also suggested that it is natural to suppose that at least some individuals might be prepared to take at least some risks in order to avoid harm to tangible cultural heritage. Yet, as I argued here, this is not something that commanders should take into consideration when deciding what to do. Due to the nature of armed conflict and due to epistemological constraints, it is hard to distinguish those individuals who might consent from those who do not. Moreover, even if a few of those whose lives are at stake might consent to the risk, it does not follow that it is morally permissible to impose a risk of serious harm on the group as a whole. To the contrary, if at least some individuals do not consent to the risk, this too might qualify as imposing a non-consensual risk of serious harm on individuals, which again is likely to be the greater evil. In sum, there are strong reasons to be skeptical of the claim that combatants are morally required to impose non-negligible risks of serious harm on civilians in order not to endanger tangible cultural heritage. ${ }^{57}$

Stockholm University william.bulow@philosophy.su.se

\section{REFERENCES}

Bazargan-Forward, Saba. "Standards of Risk in War and Civil Life." In The Nature of Peace and the Morality of Armed Conflict, edited by Florian Demont-Biaggi, 65-82. Cham, Switzerland: Springer International Publishing, 2017.

Bevan, Robert. The Destruction of Memory: Architecture at War, 2nd ed. London: Reaktion Books, 2016.

Brunstetter, Daniel R. "A Tale of Two Cities: The Just War Tradition and Cultural Heritage in Times of War." Global Intellectual History 4, no. 4 (2019): 369-88. Christie, Lars. "Distributing Death in Humanitarian Interventions." In Who

57 This paper has been written during my time as a postdoctoral research fellow in the Arts and Humanities Research Council (UK)-funded Heritage in War project, grant number AH/ P015077/1. I have had the opportunity to present earlier versions of this paper on a number of occasions where I have received valuable comments and input. I especially wish to thank Marko Ahteensuu, Patrik Baard, Krister Bykvist, Rasa Davidaviciute, Romy Eskens, Helen Frowe, Bob Hartman, Lisa Hecht, Jens Johansson, Shawn Kaplan, Simon Kirchin, Polaris Koi, Gerald Lang, Joshua Lewis Thomas, Derek Matravers, Veronique Munoz-Darde, Maria Nordström, Jonathan Parry, Juha Räikkä, and Helena Siipi. A special thanks also to one of the anonymous reviewers for this journal for very helpful and constructive comments. 
Should Die? The Ethics of Killing in War, edited by Ryan Jenkins, Michael Robillard, and Bradley Jay Strawser, 186-202. Oxford: Oxford University Press, 2018.

De Lee, Nigel. "Moral Ambiguities in the Bombing of Monte Cassino." Journal of Military Ethics 4, no. 2 (2005): 129-38.

Frowe, Helen. "Lesser-Evil Justifications for Harming: Why We're Required to Turn the Trolley." Philosophical Quarterly 68, no. 272 (July 2018): 460-80.

Frowe, Helen, and Derek Matravers. "Conflict and Cultural Heritage: A Moral Analysis of the Challenges of Heritage Protection.” J. Paul Getty Trust Occasional Papers in Cultural Heritage Policy, no. 3, 2019. https://www.getty.edu/ publications/occasional-papers-3/.

Hansson, Sven Ove. The Ethics of Risk: Ethical Analysis in an Uncertain World. New York: Palgrave Macmillan, 2013.

Harding, Sarah K. "Value, Obligation and Cultural Heritage." Arizona State Law Journal 31, no. 1 (1999): 291-354.

Hermansson, Hélène, and Sven Ove Hansson. "A Three-Party Model Tool for Ethical Risk Analysis." Risk Management 9, no. 3 (July 2007): 129-44.

Janowski, James. "Bringing Back Bamiyan's Buddhas." Journal of Applied Philosophy 28, no. 1 (February 2011): 44-64.

- "Resuscitating Bamiyan's Buddhas? A Dispatch from Dresden, Two Lessons Learned." In Ethics and Critical Thinking in Conservation, edited by Pamela Hatchfield, 95-108. Washington, DC: American Institute for Conservation of Historic and Artistic Works, 2013.

Korsmeyer, Carolyn. Things: In Touch with the Past. Oxford: Oxford University Press, 2019.

Matthes, Erich Hatala. "Authenticity and the Aesthetic Experience of History." Analysis 78, no. 4 (October 2018): 649-57.

- "Palmyra’s Ruins Can Rebuild Our Relationship with History." Aeon, March 8, 2017. https://aeon.co/ideas/palmyras-ruins-can-rebuild-our -relationship-with-history.

- "'Saving Lives or Saving Stones?' The Ethics of Cultural Heritage Protection in War." Public Affairs Quarterly 32, no. 1 (January 2018): 67-84.

- "Who Owns Up to the Past? Heritage and Historical Injustice." Journal of the American Philosophical Association 4, no. 1 (Spring 2018): 87-104.

McMahan, Jeff. Killing in War. Oxford: Oxford University Press, 2009. - "The Just Distribution of Harm between Combatants and Noncombatants." Philosophy and Public Affairs 38, no. 4 (Fall 2010): 342-79.

- "Proportionality and Necessity in Jus in Bello." In The Oxford Handbook 
of Ethics of War, edited by Seth Lazar and Helen Frowe, 418-39. New York: Oxford University Press, 2018.

Oberdiek, John. "The Moral Significance of Risking." Legal Theory 18, no. 3 (September 2012): 339-56.

Øverland. Gerhard. "High-Fliers: Who Should Bear the Risk of Humanitarian Intervention?" In New Wars and New Soldiers: Military Ethics in the Contemporary World, edited by Paolo Tripodi and Jessica Wolfendale, 69-86. Farnham, UK: Ashgate, 2011.

Song, Fei. "Rights against High-Level Risk Impositions." Ethical Theory and Moral Practice 22, no. 3 (June 2019): 763-78.

Stone, Peter G. "The Challenge of Protecting Heritage in Times of Armed Conflict." Museum International 67, nos. 1-4 (2015): 40-54.

"A Four-Tier Approach to the Protection of Cultural Property in the Event of Armed Conflict." Antiquity 87, no. 335 (March 2013): 166-77.

Timmerman, Travis. "A Case for Removing Confederate Monuments." In Ethics Left and Right: The Moral Issues that Divide Us, edited by Bob Fischer, 513-22. New York: Oxford University Press, 2020.

Thompson, Janna. "Art, Property Rights, and the Interests of Humanity." Journal of Value Inquiry 38, no. 4 (December 2004): 545-60.

_ . "War and the Protection of Property." In Civilian Immunity in War, edited by Igor Primoratz, 239-56. Oxford: Oxford University Press, 2007.

Van der Auwera. Sigrid. "UNESCO and the Protection of Cultural Property during Armed Conflict." International Journal of Cultural Policy 19, no. 1 (2013): 1-19. Voorhoeve, Alex. "How Should We Aggregate Competing Claims?" Ethics 125, no. 1 (October 2014): 64-87.

Walzer, Michael. Just and Unjust Wars: A Moral Argument with Historical Illustrations, 5th ed. New York: Basic Books, 2015.

Weiss, Thomas G., and Nina Connelly. "Cultural Cleansing and Mass Atrocities Protecting Cultural Heritage in Armed Conflict Zones." J. Paul Getty Trust Occasional Papers in Cultural Heritage Policy, no. 1, 2017. https://www.getty. edu/publications/pdfs/CulturalCleansing_Weiss_Connelly.pdf. 